РОЗВИТОК НАУКОВИХ ДОСЛІДЖЕНЬ ІЗ ПРОБЛЕМ ОСВІТНЬОЇ ІНТЕГРАЦІЇ В УКРАЇНСЬКІЙ ПЕДАГОГІЦІ (КІНЕЦЬ XX - ПОЧАТОК ХХІ СТОЛІТТЯ)

\title{
DEVELOPMENT OF SCIENTIFIC RESEARCH ON EDUCATIONAL INTEGRATION ISSUES IN UKRAINIAN PEDAGOGY (END OF XX - THE BEGINNING OF THE XXI CENTURY)
}

Удк 37.01

DOI https://doi.org/10.32843/2663-60852019-14-2-10

\section{Козловський Ю.М.,}

докт. пед. наук, доц., завідувач кафедри педагогіки та соціального управління

Національного університету

«Львівська політехніка»

\section{Козловська І.М.,}

докт. пед. наук,

провідний науковий співробітник

Міжнародного інституту освіти,

культури та зв'язків з діаспорою

Національного університету

«Львівська політехніка»

Білик О.С.,

канд. пед. наук,

доцент каредри іноземних мов

Національного університету

«Львівська політехніка»

\begin{abstract}
Стаття присвячена визначенню можливостей інтегративного підходу в освіті, базуючись на історичному досвіді України. За останні десятиліття українські педагоги накопичили значний досвід у теорії та практиці інтеграції в освіті. Проведено аналіз теоретичних розробок та засріксованого практичного досвідуінтеграціїзмісту, фрорм, методів та засобів навчання. Показано, що низка з цих розробок має значний потенціал для вирішення ключових питань освітнього процесу у всіх типах навчальних закладів. Виявлена потреба зміцнення теоретичного обгрунтування емпіричної роботи викладачів у сфрері освітньої інтеграції. Висновки зроблено на основі проведеного аналізу опублікованих праць з даної тематики протягом досліджуваного періоду (1992-2018рр.). Проведений аналіз також дозволив визначити основні тенденції розвитку інтеграціі в освіті Це дослідження показало аспекти інтеграції, які є принципово важливими для іï подальшого розвитку, виходячи з аналізу історичного досвіду. Можна передбачити зростання ролі інтегрованого навчання в усіх типах навчальних закладів.

Ключові слова: розвиток, наукові дослідження, інтеграція, освітня інтеграція, українська педагогіка, тенденції розвитку, кінець XX - початок XXI століття.
\end{abstract}

The article focuses on identifying opportunities for integrative approach in education as based on historical experience of Ukraine. Over the recent decades, Ukrainian pedagogues have acquired significant experience in the theory and practice of integration in education. An analysis was conducted for theoretical developments and the recorded practices for integrating the content, forms, methods, and means for learning. It was shown that a number of the developments have huge potential to solve key issues in educational process in all types of schools. The need has been identified to enhance theoretical justification for empirical work of lecturers in the area of education integration. Conclusions were developed on the basis of analysis conducted for published works on the topic for the period under research (1992-2018). The analysis also helped to identify key trends for the development of integration in education (enhanced interaction and cooperation of integrative approach with leading modern trends in the development of science and education, such as synergetic, informational, and competence-based, creative, a.o.: integrative educational systems have a huge potential for further development; development of methodologies for integrative educational environment; integration of modern information technologies into the training process; gradual reconstruction of conventional system of subject-based learning in Ukraine through the integrative subject-based to the integrative system, etc.).

The research showed the aspects of integration that are crucial for its further development as based on the analysis of historical experience (development of characteristics of integration: kinds, types, methodology of specific method guides, development and establishment of the theory of integrated courses: highlighting the notion of educational integrology as a research discipline of integrative processes in education; developing the models for integration of knowledge; developing the methodologies for integrated learning; developing the intercycle integration; actualizing the problem of training teachers to implement the integrated learning; developing integrated learning means; enhancing integrative processes in high school, etc.). It may be expected to have the higher role of integrated learning in all types of educational establishments.

Key words: development, scientific research, integration, educational integration, Ukrainian pedagogy, tendencies of development, the end of the $X X$ - beginning of the XXI century.
Постановка проблеми у загальному вигляді. На межі XX-XXI століть кількість публікацій 3 тематики інтеграції в освіті постійно зростає. Дослідження едукаційного аспекту інтегративних процесів в Україні містить значні теоретичні напрацювання, які доповнюється емпіричними розробками викладачів-практиків. Без сумніву, розумне впровадження інтеграції змісту, форм та методів навчання спроможне суттєво підвищити якість результату просресійного навчання. Окрім того, існує значний потенціал економічного ефеекту за рахунок усунення дублювання у змісті навчання різних дисциплін.

Інтегративні процеси можуть бути особливо вдало використані в освіті країн, які розвиваються після розпаду Радянського Союзу, зокрема в Україні. Низка методологічних обмежень у радянські часи призвела до певного викривлення загальних ідей едукації, зокрема інтеграційних процесів. Це уповільнило розвиток як теоретичного, так і емпіричного аспекту проблематики в педагогічній науці країни.

Ще одна проблема вимагає розгляду та коректного вирішення. До 1991 року всі досягнення українських наук про освіту офріційно належали так званій «радянській» науці. Тому в період фоормування державності багато цінних доробків не перейшли в спадщину української науки, а були присвоєні іншими пострадянськими країнами. Українська педагогіка змушена була фрактично відвойовувати низку своїх наукових досягнень. Багато труднощів викликав і масовий виїзд науковців за межі України.

Наукове осмислення інтеграційних процесів світовою спільнотою зумовило швидке наростання кількості досліджень з даної проблематики в 
Україні. Найбільш вагомі розробки стратегічного характеру належать академіку С. Гончаренку. Зокрема, він зазначає, що ці проблеми чітко проявляються у фрормуванні змісту освіти: «проблему змісту ми намагаємося розв'язати емпірично, шляхом спроб і в основному помилок. Вигадуємо нові навчальні предмети і виключаємо традиційні, які забезпечують фрундаментальність освіти. Наукове осмислення інтеграційних процесів світовою спільнотою зумовило швидке наростання кількості досліджень з даної проблематики в Україні. Найбільш вагомі розробки стратегічного характеру належать академіку С. Гончаренку. Зокрема, він зазначає, що ці проблеми чітко проявляються у формуванні змісту освіти: «проблему змісту ми намагаємося розв'язати емпірично, шляхом спроб і в основному помилок. Вигадуємо нові навчальні предмети і виключаємо традиційні, які забезпечують фрундаментальність освіти. За емпіричного розв'язання проблеми виникає безліч складних питань, на які важко знайти відповідь» [1, с. 23].

Розвивались теоретичні засади та низка науково-методичних праць, узагальнених у роботі «Інтегративні процеси у професійній освіті» (2010). Почали фрункціонувати наукові школи 3 проблем інтеграції (Львів, Полтава, Харків), Водночас багато проблем, які стосуються розвитку цілісної теорії інтеграції в освіті, ще потребують свого окремого дослідження.

Таким чином, визначення перспектив забезпечення ефрективності навчання вимагає ґрунтовного дослідження едукаційних інтегративних процесів на теренах України.

Важливо дослідити і розділити наукові досягнення в розвитку теорії і практики інтеграції від прожекторських та лжеінтегративних проектів, які лише створюють ілюзію інтегративних процесів. Це вимагає серйозного історико-педагогічного дослідження та виділення реальних можливостей та результатів упровадження інтеграції в освітній процес. Перша спроба аналізу досягнень інтеграції в Україні зроблена в запропонованій статті.

Аналіз останніх досліджень і публікацій. Зауважимо, що до історичного аспекту інтеграції в освіті зверталося немало дослідників, однак їхні інтереси стосуються переважно першої половини чи перших трьох чвертей $\mathrm{XX}$ століття. Зроблено також певні дослідження щодо останньої чверті XX та початку XXI століття, однак вони стосуються інших пострадянських країн і практично не містять інорормації про розвиток інтегративних процесів в українській освіті. Серед історичних досліджень, спрямованих на узагальнення і використання найбільш вдалих і ефективних практичних розробок, що випливають 3 емпіричного досвіду інтеграції та її теоретичного осмислення, присвячена цілковито розвитку інтеграції робота І. Пастирської, яка зазначає, що «проблема інтеграції змісту освіти була поставлена в другій половині XX століття, коли активно розглядалися питання узагальнення і систематизації знань, міжпредметних зв'язків, фрормування світогляду. Значний потенціал інтеграції в педагогіці підтверджується науковими розробками щодо інтеграції окремих предметів, методик, технологій. Інші науковці торкаються цієї проблеми лише епізодично» [6, с. 176].

Виділення невирішених раніше частин загальної проблеми. Окремі аспекти, розкриті в дослідженнях, стосуються переважно радянського періоду в історії України. Водночас опис та представлення в науково-педагогічній літературі інтегративних процесів стрімко зростає: серед них наявні як ґрунтовні наукові праці, так і доволі примітивні роботи, повтори одних і тих же фрактів у багатьох статтях та монографіях. Однак основна з причин такого стану - відсутність цілісного історичного дослідження з даної проблеми. Звичайно, це тривала за часом і велика з обсягом робота, перші кроки якої ми апробуємо в даній статті.

Мета статті - узагальнення основних теоретичних досліджень та аналіз засріксованого практичного досвіду едукаційної інтеграції в Україні для створення відповідних теоретичних концепцій та прогнозів щодо покращення профресійної підготовки орахівців.

Виклад основного матеріалу. Автори цієї статті пропонують до розгляду результати аналізу розвитку інтеграційних процесів в Україні, проявів та наслідків використання інтеграції (передусім за ознакою сили їх впливу на результат навчання), що на базі більш глибоких досліджень дозволяє сорормувати певні загальні закономірності едукаційної інтеграції та підвищити ефективність навчального процесу.

Надзвичайно різні означення демонструють дослідники в галузі едукаційної інтеграції. Десрініцій терміну «інтеграція» нині налічується десятки, а ідеї інтеграції проникли фрактично в усі галузі освіти. У 1993 році на сесії ЮНЕСКО було прийнято трактування інтеграції знань як органічного взаємозв'язку, взаємопроникнення, що визначається її результатом - фрормуванням єдиної інтеграційної картини світу. Виходячи з викладеного вище, пропонуємо наше трактування поняття. Едукаційна інтеграція - це процес встановлення істотних зв'язків між елементами, в результаті чого формується цілісна система з якісно новими властивостями. Зауважимо, що, на відміну від інших процесів, вихідні елементи інтегрованої системи зберігають свої індивідуальні властивості.

Очевидно, що паралельний розвиток інтегративного та предметного навчання в Україні ускладнює створення концептуальних ідей та розроблення конкретних методик навчання. Предметне навчання дуже поширене і має давні традиції. Тому іноді ці види навчання конолліктують. 
Інтегративне навчання активно розвивається в останні десятиліття. Його перспективність зумовлена тим, що воно спирається на сучасні загальнонаукові підходи (синергетичний, системний, інформаційний, креативний тощо). Переваги інтегративного навчання в різних освітніх галузях доцільно об'єднати, щоб створити більш повне уявлення про систему знань і умінь професійної підготовки фрахівця.

Українські автори в переважній більшості займають оптимістичну позицію у даному питанні. Однак маємо відсутність цілісного аналізу проблеми. Тоді до уваги не беруться недоліки інтегративного підходу, що з часом приводить до негативного ставлення частини педагогів до інтеграції в навчанні.

Складною проблемою у розвитку освітньої інтеграції в Україні $€$ пострадянські впливи, від яких нелегко позбутися навіть через багато років. Вони пронизували всю освітню систему і вели до фрормального використання інтеграції в освіті та підміни наукових ідей кон'юнктурними.

Процес навчання фрахівця обходиться дорого (державі чи студентам-платникам), тому пошук засобів підвищення якості засвоєння профресійних знань та умінь $є$ надзвичайно актуальним. ще дорожче обходиться роботодавцям та молодим спеціалістам «доучування» на місці роботи як тяжкий спадок радянської епохи. Адже не завжди і не для всіх спеціальностей можна знайти добре підготованого спеціаліста, якого потребує роботодавець. Едукаційна інтеграція є одним зі шляхів вирішення цієї складної проблеми.

Матеріалами для дослідження служили: переліки захищених дисертацій у бібліотеках України; провідні (пізніше фрахові) видання з педагогічних наук (1991-2018рр.) в Україні, а також педагогічні матеріали, видані в Україні протягом досліджуваного періоду [7; 8].

Хронологічний аналіз показує, що в другій половині $X X$ століття найінтенсивніше розвивалися напрями освітньої інтеграції для підготовки майбутніх робітників. Наприкінці 80-х - початку 90-х років виходить друком багато методичних матеріалів для професійної нижчої школи (Львівська наукова школа). Однак уже наприкінці століття різко зростає кількість розробок для вищої школи (Харківська наукова школа). Водночас активізується Полтавська наукова школа, яка пропонує програму «Довкілля» та інтегруючі природничі дисципліни в загальній школі в курси природознавства. Більш детальний аналіз із хронологічного аспекту інтеграції в Україні показує, що співвідношення «кількість авторів/кількість публікацій» досить сильно змінювалась протягом субперіодів 1998-2003 рр. та 2009-2014 рр. У ці періоди налічується у середньому 2-4 публікації на одного автора за рік, а в інші періоди - до 10 і більше публікацій на одного автора за рік із проблем інтеграції.
Це пояснюємо тим, що в певні періоди проблематика інтеграції стає популярною в освітніх колах, і з'являється багато публікацій авторів, які ні до цього, ні пізніше до проблем інтеграції більше не звертаються у своїх публікаціях. I навпаки наявна досить велика група авторів, які постійно працюють у галузі едукаційної інтегрології.

Таблиця 1

\section{Періодизація історичного розвитку освітньої інтеграції в Україні}

\begin{tabular}{|c|c|}
\hline Роки & Зміст етапу \\
\hline $\begin{array}{c}1991- \\
2001\end{array}$ & $\begin{array}{l}\text { поняття інтеграції адаптувалося із } \\
\text { загальнонаукового в педагогічне } \\
\text { розроблення характеристик інтеграції: видів, } \\
\text { рівнів, типів інтеграції, її методології, шляхів } \\
\text { впровадження } \\
\text { апробації численних інтегрованих курсів, } \\
\text { експериментування щодо } \\
\text { інтегрованих занять } \\
\text { виокремлюється поняття «дидактична } \\
\text { інтегрологія» як галузь дослідження } \\
\text { інтегративних процесів у освіті }\end{array}$ \\
\hline $\begin{array}{c}2002- \\
2010\end{array}$ & $\begin{array}{l}\text { зміщуються акценти від міжпредметних } \\
\text { зв'язків та професійного спрямування } \\
\text { до інтеграції змісту навчання } \\
\text { у професійній школі } \\
\text { початки конструювання систем навчання } \\
\text { на основі інтеграції знань } \\
\text { розробки моделей інтеграції знань } \\
\text { розвиток методик інтегрованого навчання } \\
\text { подальше поширення інтегрованих курсів } \\
\text { і розроблення нових } \\
\text { актуалізація проблем міжциклової інтеграції } \\
\text { (гуманітарних та природничих дисциплін) } \\
\text { поява досліджень із проблем інтеграції } \\
\text { у сорері виховання } \\
\text { аналіз можливості інтегративного підходу у } \\
\text { сфрері фрормування загальнолюдських } \\
\text { та профресійних якостей особистості }\end{array}$ \\
\hline $\begin{array}{c}2011 \text { - } \\
\text { доте- } \\
\text { пер }\end{array}$ & $\begin{array}{l}\text { провідне місце зайняли дослідження з } \\
\text { проблем підготовки педагогів до реалізації } \\
\text { інтегрованого навчання } \\
\text { розробки інтегрованих засобів навчання } \\
\text { зростання значущості міжциклової інтеграції } \\
\text { посилення інтеграції гуманітарних та } \\
\text { природничих дисциплін } \\
\text { конструювання моделей змісту } \\
\text { інтегративного навчання для конкретних груп } \\
\text { і циклів навчальних дисциплін } \\
\text { посилення інтегративних процесів } \\
\text { у вищій школі }\end{array}$ \\
\hline
\end{tabular}

Узагальнюючи викладене вище, констатуємо оформлення теорії міжпредметних зв'язків у змісті навчання для всіх видів навчальних закладів. На цей час припадає поява великої кількості інтегрованих курсів.

Протягом 25 років в Україні теорія освітньої інтеграції від епізодичних досліджень перейшла до системних. Ключовим для розвитку цієї теорії було введення поняття дидактичної інтегрології (Козловська, 1999) як галузі наукового знання про суть, закономірності та застосування інтеграції. 
У межах едукаційної інтегрології були виявлені провідні закони освітньої інтеграції та їхні наслідки. Це був перехід до нової якості в розвитку освітньої інтеграції: стало можливим повноцінне використання цієї теорії для конкретних видів, напрямів, профрілів підготовки фрахівців.

На думку авторів, це висуває на перший план як теоретичні контексти, так і стимул до побудови моделей інтеграції для конкретних навчальних курсів, закладів і об'єктів.

Багато викладачів-практиків розуміють важливість інтеграції та самотужки намагалися створювати інтегративні курси, навчальні матеріали, новітні методи, форми та засоби навчання на засадах інтеграції. Очевидно, що аналіз практичного досвіду викладачів є завданням дуже громіздким і виходить далеко за межі нашого дослідження. Однак варто взяти до уваги, що в майбутньому таке дослідження варто буде провести.

Одним із найважливіших практичних результатів впровадження освітньої інтеграції протягом означеного історичного періоду в Україні $€$ підвищення готовності учнів, студентів та викладачів до подальшого навчання і професійного зростання. Зокрема, в процесі опитування респонденти пояснили цей ефект як результат нового бачення отримуваних знань та вмінь у взаємозв'язках. Причому ці зв'язки є природними та суттєвими. Вони дозволяють скоротити обсяги навчального матеріалу, узгодити близькі теми під час вивчення споріднених навчальних дисциплін тощо.

Висока результативність саме інтегративних зв'язків (на відміну від міжпредметних) пов'язана 3 тим, що вони володіють не тільки когнітивними, але й організаційними можливостями.

Протягом 1992-2018рр. інтегративні процеси поступово витісняють міжпредметні зв'язки, оскільки останні спрямованні лише на зміст навчання. Інтеграція ж дозволяє задіювати і вміння, методи, фрорми, засоби навчання. Існують позитивні приклади інтеграції навчальних закладів різних рівнів акредитації, а також загальноосвітніх, професійних та наукових установ.

ще одним практичним результатом інтеграції в останнє десятиріччя в Україні є одночасне використання проблемного та інтегративного підходів в освітньому середовищі STEM-освіти. Особливо яскраво ці переваги виявляються в умовах професійної освіти.

Таким чином, із прагматичної точки зору, протягом означеного історичного періоду в традиційне навчання поступово включалися інтеграційні елементи.

Зауважимо, що процес наростання інтеграції в освіті в останні двадцять років розвивається по висхідній. Крім того, розширюється масштаб інтеграції та перелік охоплених нею об'єктів (підготовка викладача, міждисциплінарні зв'язки, інтегровані фрорми і методи навчання, інтеграція наукової та навчальної діяльності, створення інтегративних комплексів тощо).

Це дослідження показало аспекти інтеграції, які $€$ принципово важливими для її подальшого розвитку, виходячи з аналізу історичного досвіду. Одночасна інтеграція знань, умінь, методів, фрорм і засобів навчання суттєво покращує результат навчання, мотивацію студентів і учнів, посилення зв'язків з реаліями життя та профресії. Це відбувається завдяки тому, що саме інтеграція базується на відродженні природних, об'єктивно існуючих між елементами зв'язків.

Чітко простежуються тенденції: посилення взаємодії та кооперації інтегративного підходу з провідними сучасними напрямами розвитку науки і освіти: синергетичним, інфрормаційним, компетентнісним, креативним тощо; інтегративні освітні системи мають значний потенціал для розвитку; розвиток методик для інтегративного освітнього середовища; інтеграція сучасних інформаційних технологій у навчальний процес; поетапна перебудова традиційної системи предметного навчання в Україні через інтегративно-предметну - до інтегративної системи. Можна передбачити зростання ролі інтегрованого навчання в усіх типах навчальних закладів.

Узагальнення історичного досвіду інтегративних процесів у сучасній освіті є своєчасним у світлі реалій навчального процесу в усіх типах навчальних закладів України. Водночас дискусійними є питання щодо труднощів упровадження інтегративних концепцій і методик у практику роботи. По-перше, це вимагає додаткової підготовки викладача та його мінімального ознайомлення із суміжними дисциплінами. Однак така освідомленість допомагає викладачеві краще усвідомити роль і фрункції власного предмету викладання. По-друге, на певних етапах інтеграційний підхід вимагає певного переструктурування змісту освіти. А це у свою чергу веде до перегляду навчальних планів і програм, а також їх координації для різних освітніх закладів тощо. Ще однією небезпекою $є$ так звана «лже-інтеграція», тобто підміна інтегративних процесів фрормальними процедурами. Результати такої підміни створюють видимість інтеграції, однак не забезпечують позитивних ефектів у навчанні. У деяких випадках така лже-інтеграція може завдати серйозної шкоди, бо порушує усталену систему навчання, а не може запропонувати кращого варіанту. Існують наразі труднощі в термінологічному апараті. Хоча протягом історичного розвитку пропонувалися різні фрункції інтеграції, однак загальноприйнятого місця в освітній системі наразі вона не має в українських освітніх науках.

Незважаючи на дискусійні моменти щодо ролі інтеграції в освіті, український досвід показує, що позитивні результати інтеграції значно перевищують названі вище труднощі. 
Висновки. Основна мета дослідження полягала в аналізі можливостей інтеграції і визначення її статусу в сучасній українській педагогіці. Для цього узагальнено емпіричний досвід інтеграції, оцінено рівень та стан розвитку теорії, розмежовано наукові розробки 3 інтеграції від прожекторських її описів, прогнозовано перспективи і проблеми, які ще потребують вирішення. Основними результатами розвитку інтегративних процесів в українській освіті вважаємо: впровадження поняття «інтеграція» в термінологічний апарат освіти; розроблення характеристик інтеграції: видів, рівнів, типів, методології, конкретних методик, розробки та становлення теорії інтегрованих курсів: виокремлення поняття едукаційної інтегрології як галузі дослідження інтегративних процесів в освіті; розробки моделей інтеграції знань; розвиток методик інтегрованого навчання; розвиток міжциклової інтеграції; актуалізація проблеми підготовки педагогів до реалізації інтегрованого навчання; розробки інтегрованих засобів навчання; посилення інтегративних процесів у вищій школі тощо. Загалом, інтеграція передбачає забезпечення плавного переходу, без стресових ситуацій, від традиційної до інноваційної освіти. Дослідження з даної проблематики в України зростають як кількісно, так і якісно та мають великі перспективи для переосмислення освітнього процесу. Сподіваємось, що український досвід едукаційної інтеграції може бути використаний в інших країнах, рівно як в Україні успішно вивчається та використовується досвід інтеграції зарубіжних країн.

Перспективою подальших досліджень $є$ розвиток теоретичних основ педагогіки науково-педагогічної діяльності, обґрунтування інтегративних зв'язків наукового та навчального процесу, використання методу моделювання для можливостей науково-дослідної роботи, конкретизація моделей для конкретних профрілів і напрямів підготовки 3BO.

\section{БІБЛІОГРАФІЧНИЙ СПИСОК:}

1. Гончаренко С.У. Дидактична концепція змісту освіти. Сучасні інфрормаційні технології та інноваційні методики навчання в підготовці фрахівців: методологія, теорія, досвід, проблеми. КиївВінниця, 2002. С. 22-26.

2. Інтегративні процеси у профеесійній освіті. Львівська наукова школа: збірник наукових праць / за ред упор. Б.Т. Камінський, І.Я. Пастирська. Львів : Сполом, 2009. 410 с.

3. Козловська І.М. Теоретичні та методичні основи інтеграції знань учнів профресійно-технічної школи : дис. ... д-ра пед. наук : 13.00.04; АПН України ; Інститут педагогіки і психології професійної освіти. Київ, 2001. 464 арк. : рис. Арк. 383-409.

4. Козловський Ю. М. Інтеграційні процеси в просресійній освіті: методологія, теорія, методики : монографрія. Львів : Видавництво Львівської політехніки, 2018. 420 с.

5. Білик О., Козловський Ю., Козловська І. Особливості принципу призначення знань у профресійній школі. Педагогічні інновації у фраховій освіті. 2014. № 1 (5). С. 108-116.

6. Пастирська І. Інтеграція змісту предметів природничого і гуманітарного циклів як загальнопедагогічна проблема (кінець XX-початок XXI століття): дис. ... на здобуття наукового ступеня кандидата педагогічних наук зі спеціальності : 13.00.01 Загальна педагогіка та історія педагогіки. Хмельницький національний університет, Хмельницький, 2012. 261 с.

7. Фонди Національної бібліотеки України ім. В. Вернадського (дисертації та автореферати).

8. Періодичні видання й дидактичні джерела України означеної доби (науково-методичні здобутки педагогів; навчальні програми, навчальні плани, підручники і навчальні посібники; монографрії). 